\title{
Water Trade from an Islamic Business Ethics Perspective: Evidence from Indonesia
}

\author{
Bahrina Almas ${ }^{1}$ \\ Universitas Airlangga \\ Surabaya, Indonesia \\ almascairo@gmail.com \\ Tjiptohadi Sawarjuwono ${ }^{2}$ \\ Universitas Airlangga \\ Surabaya, Indonesia \\ tjiptohadi@feb.unair.ac.id \\ Sri Iswati ${ }^{3}$ \\ Universitas Airlangga \\ Surabaya, Indonesia \\ iswati.feua@gmail.com
}

\begin{abstract}
Water is a very important component for the survival of beings on earth. However, not all humans utilize water resources well to realize life benefit. There are several issues related to water resources in this decade, such as privatization and commercialization. Water resources that should belong to the general public move to the hands of certain people only, there by affecting the scarcity of water among surrounding communities. This study aims to review the management of water resources in accordance with the values and norms in Al-Quran and As-Sunnah. There is a variety of water resources management permissible in order to meet the needs of the community. This study is a conceptual paper that examines how water resources in Indonesia should be managed in terms of theories of production according to Islam, especially ethics. Islam is the religion of rahmatan lil'alamin, which strictly prohibits all forms of damage and activities that cause harm. Therefore, water resources that are part of the determinants of human survival need to be managed to achieve the benefit of the people.
\end{abstract}

Keywords: Islam, Business Ethics, Commercialization, Water

\section{INTRODUCTION}

The term ecology is increasingly popular with the flourishing phenomenon of environmental degradation due to excessive utilization and the human tendency to separate environmental concerns with survival. According to Otto Soemarwoto, an ecosystem is a central concept in ecology and an ecological system is formed by the mutual relationship between living things and their environment. Ecosystems are formed by living components and do not live in a place that interacts to form a regular unity. Each component performs its function and works well together, so that the ecosystem's order is maintained (Supriadi, 2006).

Water is the creation of God as the source of human life and other creatures on earth. Therefore, the utilization of water resources must be based on responsibility and, thus, the welfare of mankind is achieved. Islam is the religion of rahmatan lil'alamin, which teaches people to always be balanced in interacting with the environment. Allah, SWT, has created the universe to be used as well as possible for the improvement of the quality and welfare of life (Ari, 2007). Islam does not allow all things that cause harm, especially related to the management of natural resources that Allah, SWT, granted to meet all the needs of human life in the world.

Based on these matters, water management must also be balanced and in harmony with natural law, responsible, fair and empowering the community (Aziz and Saharani, 2007). The utilization of clean water resources should be as much as possible for the welfare and prosperity of the community, so that the availability and distribution of clean water sources must be comprehensively planned and meet the principles of expediency, fairness, independence, sustainability and sustainability (Atyanto, 2006). These things need to be considered because, if not, it will cause environmental damage that threatens the survival of human life and causes economic losses.

Nationally, the availability of water in Indonesia reaches 694 billion $\mathrm{m} 3$ per year. This amount is basically a potential that can be utilized, but the fact is that, currently, only about $23 \%$ of that has been utilized, whereby only about $20 \%$ of which is utilized is used to meet the raw water needs of households, cities and industry and the other $80 \%$ is used to meet the needs of irrigation (Hartoyo, 2010). The more potential water resources in Indonesia emerge, so too are the problems faced related to the management of water resources related to ecology.

In recent years, there have been several water shortage phenomena and even drought has hit some areas in Indonesia. Ironically, drought-stricken areas are the areas that have the largest water source in Indonesia. Sukabumi, for example, is 
a city currently with abundant water source, but even Sukabumi experienced the impact of massive exploitation by the Air Minum Dalam Kemasan Company (drinking water). These companies not only utilize springs from surface water, but also drill groundwater resulting in the shrinking surface water volume. As a result, the water source for the community has decreased drastically, especially during the dry season so that, in recent years, some areas in Sukabumi need clean water installation to help save the local population.

According to research by Syaeful Anwar (2016), entitled Commercialization of Water Resources according to Islamic Law: A Case Study in Padarincang Village, Serang, Banten, the practice of commercialization of water resources in Padarincang Village caused more damage than benefit. This is evidenced by the phenomenon of difficult access to clean water by local residents, causing drought. The establishment of bottled drinking water companies is not prohibited in Islamic law, although, in the hadith, there are prohibitions of Muslims union in three respects, namely water, fire and grasslands. However, if the purpose of the establishment of drinking water companies is so that people can easily drink water and open up jobs, this is not prohibited during the creation benefit ummah.

Water resources phenomena in Indonesia can be seen to refer to the legalization of privatization of water resources in Law No. 7/2004. The creation of the water privatization law on 19 February, 2004 was followed by the issuance of a number of local regulations related to the privatization of water resources. This privatization of water resources contributes greatly to water shortages and even prolonged drought in the dry season. Law No.7/2004 provides the privatization of drinking water supply and control of water resources (groundwater, surface water and some river bodies) by business entities and / or individuals. This is certainly very beneficial to the capitalists who plundered water resources so that the benefits gained can only be enjoyed by a handful of people alone.

Privatization through Law No. 7/2004 has also been the focus of Hermansyah's (t.t) research entitled Water Privatization in Indonesia: A Study of Water Resources and Islamic Economics Law. The results of this study conclude that, if examined from several articles contained in the law, it is seen that the role of the private sector in the management of water resources is so dominant that it reduces the role of the state in the sector which should be utilized for public need. The consequence of all that is that the state will gradually lose control over every stage of water resources management. As a result, the state cannot guarantee and provide protection to the public for access to clean water.

The problems related to the water resources above are studied from various perspectives, including the Islamic economy in a kaffah manner. This study considers not only the policies, policy impacts and socioeconomic societies that need to be reviewed and studied according to Islam, but an assessment of Islamic microeconomics also needs to be made so that companies, business entities or individuals who manage water resources, especially in Indonesia, understand how productive ethics should be owned by every manufacturer so as not to exceed the limit and cause environmental harm.

\section{LITERATURE REVIEW}

\subsection{Critical Review of Law No. 7/2004}

The scarcity of water resources in recent years has been the trigger for disputes that have ended in a fight. In Indonesia, the privatization of water resources is legalized by Law No. 7/2004 on Water Resources. The creation of this law was then followed by some local regulations related to the privatization of water resources, which are the cause of the water crisis. According to Herman, the issue of privatization was actually implemented in the early 1990s but only took on a legal basis in the form of Law in 2003, namely the establishment of Law No. 19/2003, which later became the reference in the implementation of privatization in Indonesia. For more detail, regulation of the implementation of this Law has also been issued, namely Government Regulation (PP) No. 33/2005 on the Procedures of Privatization of the Company.

According to Heyneadhi and Wermasubun (2004), Law No. 7/2004 limits the role of the state solely as regulators and regulators. Country as a regulator and private owner as a water system provider (privatization) is an elaboration of the application of a liberal economic system so that it loses control over every stage of water management to ensure the safe and quality of service for every water use. The ethical, social and political approach of the report may be summarized as being a call for 'joined-up' policy making. The 'audit of governance' carried out by the WHAT commissions makes it plain that many current approaches, whether founded on rational self-interest or on ethical beliefs, are as likely to be contributing to as resolving global, regional and national problems (Jeffery, 2001)

\subsection{Some Point of Exploitation of Water Resources}

Bottled drinking water companies (AMDK) are widely spread throughout Indonesia, especially areas in Java. Aqua Danone is the largest company because it was also the first AMDK company established. Currently, Aqua Danone owns 17 factories and monopolizes dozens of springs. Therefore, Aqua Danone is the biggest source of AMDK draining the water resources in this country. Sukabumi is a target city of Aqua Danone to produce mineral water as it contributes many springs. As a result, in the long run, Sukabumi people, especially the sub-districts with the largest source of water, experience lack of clean water and even drought.

In some online media it is mentioned that every person of Sukabumi, West Java, is a historical witness of the exploitation of massive water resources by capitalism. Sukabumi is a city rich in clear water springs, scattered in several sub-districts, but the people of Sukabumi, especially 
in the districts of the source of the water, actually experienced a clean water crisis. They didn't even have access for the daily needs of the community and so were forced to consume cloudy water gathered in the pools, which is practicable. Unfortunately, over the last few years the people around the Aqua Danone factory have been no longer able to irrigate their fields due to severe drought. So, the residents have been assisted by the local government to install water installations so that their rice does not fail to harvest.

In Klaten, Central Java, in 2012, the Aqua Danone factory was attacked by residents around Polanharjo district because, according to them, the operation of the factory resulted in a water debit in the Polanharjo sub-district so that people began to have difficulty getting clean water. There were not only protests about the lack of clean water for daily living needs, the Polanharjo subdistrict residents also demonstrated about the destruction of the road because Aqua Danone broke the agreement whereby heavy vehicles were supposed to pass using the west path but were still only passing on the east road, causing road damage. Not only that, the destruction of roads caused air pollution or dust that was scattered into the houses when vehicles belonging to Aqua Danone passed.

\subsection{Water in The Holy Qur'an and Sunnah}

And We made from the waters of all living things, whether they believe? "(Surat al-Anbiya ': 30). The verse describes that everything that lives on earth is the raw material is water. In another letter, "And He created the heavens and the earth in six days, and is His asry before that, that He might test which of you is better off" (Surat Hud: 7). In the verse, it explains the existence of water is much older than the age of heaven and earth.

Based on Al-Quran and As-Sunnah above, it shows how noble water was created by Allah, SWT. In the Qur'an, there are many verses that explain that this earth will die if there is no water, life on earth will also become extinct if there is no water as it is a source of human life. Therefore, all of Allah's creation is for the benefit to live for all beings, especially humans as khalifatullah fil ardh. The use and management of water should be based on a sense of responsibility and awareness of the gifts God has given so that it will not harm and cause harm to the salvation of sentient beings, especially mankind.

The Quran makes two explicit statements that support water demand management. In short, the Quran first affirms the finite nature of the global water supply and, second, it emphasizes that the water should not be wasted. The Quran then tells humans that they may use God's gifts for their sustenance, but that they should eat and drink in moderation and not waste excess amounts because God does not favor those who waste (Faruqui, 2003).

\subsection{Ownership and Water Pricing}

Man is encouraged to partake of the good things that God has provided him (Quran:5:8), but use does not imply abuse. The general principle with respect to resources that are free, e.g. air, ocean water, etc., is the following: "Any person may make use of anything that is free provided that in doing so no injury is inflicted upon any other person. Although Islam honors ownership rights, it does not consider these rights to be absolute especially if they may lead to environmental pollution and threaten public safety" (Beekun and Badawi, 2005).

The concept of wealth ownership in Islamic Jurisprudence must first be understood. Property in Islam is a social function, that is, wealth belongs to God and a person simply assumes a managerial position to increase wealth and use it properly. The word 'wealth' has no significance on its own; it is merely a relationship. However, this should not be taken to mean that Islam jeopardizes economic incentives by externalizing property. It basically balances private incentives with social optimality (Kadouri dkk, 2001).

The issue of property rights in environmental goods remains unsettled, even at the theoretical plane: do individuals have or should have these rights or the societal entity? If the two have to share these rights, when shall they do so and how? Decisions on issues of this sort do usually involve a measure of arbitrariness and, thus, tend to raise grave concern about justice and injustice. Added to these problems are the difficulties of putting policies into operation. Here, the adequacy of laws and efficiency in executing them is the question (Hasan, 2006).

\subsection{Business Ethics in Islamic Perspective}

According to Nawatmi (2010), the basic principles of ethics in Islam and its practice in business are: (1) unity; (2) equilibrium; (3) free will; (4) responsibility; (5) virtue. Unity is a reflection of the concept of tawhid that combines all aspects of life, both economic, political, social and cultural homogeneously intact, consistent and orderly.

The principle of balance emphasizes the ethical principles that are applied in the activities as well as business entities. For example, there is no cheating on scale and scale, and pricing is based on normal market mechanisms. The principle of freedom (free-will) in Islam leads to cooperation rather than competition, let alone to mutually extinguish the business and maintain cooperation contracts that have been agreed between both parties. Responsibility is a form of awareness for every action. The principle of responsibility, according to Sayyid Qutb, is a balanced responsibility in all forms and scope, between individuals and society and between communities and other societies.

In Islam, water is considered a gift from God, so no individual literally owns it. Humans are the stewards of water and other common resources that belong to the community. However, as Djebbar explains (Kadouri et al., ), most Islamic scholars have concluded that individuals or groups have the 
clear right to use, sell and recover value-added costs of most categories of water (Faruqui, 2001).

The application of ethics in business is highly emphasized in Islam so that, when a company produces and competes, it will not be a tone of injustice and it will not harm the moral, thus harming the socioeconomic society. Therefore, it is necessary to integrate the ethics in the business world so that the business activities undertaken by the company still hold the principles that bring benefits to society, not just for individuals or some people only.

\section{METHODOLOGY}

This research uses qualitative method because it has an inductive nature by taking a certain object, that is commercialization of water resources and business ethics of Islamic perspective, which the writer will then describe in discussion. Qualitative research is method to explore and understand its meaning and people are considered to come from a social or humanitarian problem. The nature of qualitative research is inductive, focusing on the meaning of the individual and translating the complexity of a problem.

There are two types of research in qualitative methods, namely library research and field research. This research uses library research, which emphasizes the library as the object of research. According to Djalaluddin (2012), research on literature emphasizes the essence contained in a book, but does not mean to examine the book. Library study is done by reviewing the ideas of experts, existing concepts and rules that bind the object of science and profession.

Another method used in this research is the vestehen method, which aims to understand the integrated interpretation between objects, as well as the understanding of the object perspective (individually or collectively) studied with its cultural and academic background. The main sources of this research consist of water resources regulations in Indonesia, the phenomenon of water resources in Indonesia and Islamic business ethics in the production and commercialization of water.

\section{DISCUSSION}

Indonesia is one of the largest in the world, not to mention the richness of its water resources. The economic crisis that occurred in Indonesia in 1997 resulted in Indonesia's debt abroad floating due to currency fluctuations. Therefore, the International Monetary Fund (IMF) is trying to help Indonesia recover the Indonesian economy. According to the KRUHA team, one of the contents of the debt agreement is to improve the management of water resources in Indonesia.

We can understand from the agreement between Indonesia and the IMF that water resources based on the paradigm of globalization is the initial step of privatization of water resources, which will lead to the commercialization of water resources in Indonesia. The most important issue of a new era in water resources reform is the water rights for surface water and groundwater allocations introduced by the World Bank.

The right to use water in the water resources law is divided into two, namely the right to use for daily necessities and the right to use water to meet commercial or business needs. The market mechanism runs as a result of market mechanisms. In this market mechanism, it is important to note that there are no clear limits on the use of water use rights, both in quantity and in time. This is important to prevent the rights holder exploiting the water excessively.

If reviewed and analyzed through Islamic business ethics, water trade (water trade), also called the commercialization of water resources, there are two sides to the coin. The production of bottled mineral water (AMDK) in Indonesia thrives with the increasing consumption of Indonesian people towards clean water. Thus, it also encourages the acceleration of economic development of Indonesia. On the other hand, the targeted areas of AMDK producers experience a 'resource curse', the term for lush areas left behind by lack of knowledge and expertise in human resources.

The phenomenon of exploitation of natural resources occurring in Sukabumi, West Java, and Klaten, Central Java, reflects the complexity of water resources management problems in Indonesia. Aqua Danone as market leader of the Air Minum Dalam Kemasan company (drinking water) in Indonesia has expanded its wings, because, in recent years, it has tried to increase the number of factories in the various abundant springs, not to mention Padarindang, Banten, and Jombang, East Java. These two areas are Aqua Danone's next targets in increasing production capacity and production share. Surprisingly, however, all residents of both regions rejected the establishment of the Aqua Danone plant because of the fate of Sukabumi and Klaten, which has been a clean water crisis and is very dangerous for the people around the factory.

In 1998, due to intense competition and the emergence of a new competitor, Aqua Golden Mississippi PT sold its shares to Danone Group on September 4, 1998. This acquisition will save Aqua Danone from new competitors. Through Islamic business ethics, Aqua Danone's production and trading activities are analyzed to find how the trade and water management activities fit into Islamic business ethics.

According to the business of Islam through the example of Prophet Muhammad, SAW, it is not allowed to do business in dangerous conditions (mudharat) that could endanger and damage individual and social life. The phenomena occurring in some areas of Indonesia violate the values and ethics recommended above in regards to nonbusiness Messages about harming and undermining individual and social life. Production activities require factors of production, especially raw materials derived from nature, but humans are limited by the need, so it is prohibited 
to exploit anything that causes environmental damage and threatens human life on earth.

\section{CONCLUSION}

Islam allows people to exploit natural resources to meet the needs of life on earth. Nature, as a factor of production, is a resource that can be explored as well as possible with the awareness and responsibility of keeping the gifts God gives to his creation on earth. But everything that causes damage and loss is strictly forbidden.

Water trade or commercialization of water resources is allowed as long as it is to meet the community's clean water needs. But restrictions are permitted for it to be prohibited if it begins to pose a threat to the salvation of the human soul. As is the case of Aqua Danone which utilizes big springs in Sukabumi and Klaten. This certainly raises anger and rejection because of its long-term impact on indigenous communities. The shortage of clean water and drought throughout the dry season is a concern for residents around the Aqua Danone plant and even the plant construction plan. People refuse to run out of factories because they not only see the short-term, i.e., opening up extensive employment, regional economic improvement and so on, but also consider the long-term impact.

Water is actually prohibited for trading, but, because buying and selling bottled water (AMDK) is now felt easier for people to get and consume clean water, then, according to some of these opinions, it is allowed. In sharia business ethics, trading and trading activities are allowed when mutually beneficial. Here, however, one party is benefited, but the other is disadvantaged. In addition, there is an imbalance between the bottled drinking water business (AMDK) and the residents around the AMDK plant. Businessmen reap huge profits from the sale of bottled water, but, on the other hand, the population will be negatively affected because the surface water volume is shrinking so that the residents find it difficult to get clean water.

\section{ACKNOWLEDGMENT}

We would like to thank the various parties who have helped, especially Prof. Tjiptohadi Sawarjuwono and Prof. Sri Iswati, so that this journal can be completed. Special thanks go to the Association of Lecturers of Magister Sains Ekonomi Islam Universitas Airlangga and Program Studi Magister Sains Ekonomi Islam Universitas Airlangga, which enabled this journal to be published.

\section{REFERENCES}

\section{[1] Al-Quran Al-Karim dan Al-Hadits}

[2] Supriadi. Hukum Lingkungan di Indonesia. Jakarta: Sinar Grafika. 2006
[3] H, Ari. Peran Islam dalam Penyelamatan Lingkungan Hidup. Jurnal Millah Vol. VI, No. 2. 2007

[4] G, Aziz and Saharani. Islam dan Konservasi Lingkungan. Jurnal Millah Vol. VI, No. 2. 2007.

[5] D, Atyanto. Model Arahan Pemanfaatan Lahan untuk Konservasi Sumber Daya Air di Kabupaten Sleman. Jurnal Manusia dan Lingkungan, Vol. 13 No. 2 Juli. 2006.

[6] Hartoyo. Program Pengembangan Penyediaan Air untuk Menjamin Ketahanan Pangan Nasional. Seminar Pengembangan dan Pengelolaan Sumber Daya Air untuk Ketahanan Pangan. Bogor: Kementrian Pekerjaan Umum. 2010.

[7] S, Anwar. Komersialisasi Sumber Daya Air menurut Hukum Islam: (Studi Kasus di Desa Padarincang, Serang, Banten). 2016. Unpulished Minor Thesis.

[8] Hermansyah. Privatisasi Air di Indonesia: Kajian atas Undang-Undang Sumber Daya Air dan Ekonomi Islam. t.t.

[9] H, Heyneadhi dan S. Wermasubun. Dagang Air: Perihal Peran Bank Dunia dalam Komersialisasi dan Privatisasi Layanan Atas Air di Indonesia. Salatiga:Widya Sari Press. 2004.

[10] J, Jeffery. Human Rights, Ethics and Governance The Work of The World Humanity Action Trust. Journal of Water Resources Development Vol. 9 No. 1, Juli 2001.

[11] N. I, Faruqui. Water, Human Rights and Economic Instruments the Islamic Perspective. Journal of Water Resources Development Vol. 10, No. 2, Juli 2003.

[12] R. I, Beekun and J. A. Badawi. Balancing Ethical Responsibility among Multiple Organizational Stakeholders: The Islamic Perspective. Journal of Business Ethics, Springer. 2005.

[13] M. T, Kadouri, Y. Djebbar and M. Nehdi. Water Rights and Water Trade: An Islamic Perspective. Water Management in Islam. Nepal Water Conservation Foundation. 2001.

[14] Z, Hasan. Sustainable Development from an Islamic Perspective: Meaning, Implications and Policy Concerns. J. KAU: Islamic Economics Vol. 19, No. 12006.

[15] S, Nawatmi. Etika Bisnis dalam Perspektif Islam. Jurnal Fokus Ekonomi April 2010, Vol. 9 No. 1 hal 50-58 2010.

[16] N. I, Faruqui. Islam and Water Management: Overview and Principles. Water Management in Islam. Nepal Water Conservation Foundation. 2001.

[17] D, Ahmad. 2012. Perspektif Islam tentang Kepemilikan Negara atas Tambang di Indonesia. Tidak Dipublikasikan. Malang: Disertasi Program Doktor Ilmu Ekonomi, Fakultas Ekonomi dan Bisnis Universitas Brawijaya. 